\title{
Racial Uplift, Interracialism, and the Employment of African American Social Workers in \\ North Carolina, I925-I95I
}

\author{
Seth Epstein
}

Charlotte Rhone began her position as a social worker in Craven County, North Carolina, early in 1926. The subtitle of a newspaper article written for an African American audience announcing "Welfare Work in New Bern" noted Rhone's selection to "represent our group" through her position. This message was repeated in the text of the article to describe the responsibilities of Rhone, who had previously been associated with Jane Addams's Hull House in Chicago. ${ }^{\mathrm{I}}$ She would go on to work for the county as a case worker into the 1940s. ${ }^{2}$ As this description of her position suggests, the state employment of African American social workers in North Carolina initially promoted the

Seth Epstein is guest researcher at the Uppsala Centre for Religion and Society, Uppsala University in Uppsala, Sweden.

The author thanks the anonymous reviewers, the editor, and the manuscript editor for their generous suggestions and assistance.

I. Caswell Carter "Welfare Work in New Bern," folder I, Correspondence, I922-I929, North Carolina Commission on Interracial Cooperation Records, I922-I974 \#03823, Southern Historical Collection, Wilson Library, University of North Carolina at Chapel Hill (hereafter cited as $\mathrm{SHC})$.

2. Larkins to Bost, "Conference with Mrs. John D. Whitford," December I2, I942, I, box 5.5, folder 17, County Consultation Reports, Bureau of Work among Negroes, State Board of Charities and Public Welfare, North Carolina State Archives, Raleigh (hereafter cited as BWAN).

The Journal of African American History (Winter 2020) (C2O2O A S ALH. I548-I867/2020/IO5OI0004 \$10.00 All rights reserved. DOI: IO.IO86/705384 
expectation that they would represent local blacks in interracial discussions with whites. In addition to social welfare services they would provide to African Americans, they would participate in what historian Kimberly Johnson has termed "Jim Crow reform," which emerged after World War I. This involved a form of interracialism that relied on cooperation, however unequal, between educated African Americans and whites to improve but not transform the "Jim Crow order."3

Reverend Robert Isaiah Johnson, rector of St. Cyprian's Episcopal Church in New Bern, credited Lawrence A. Oxley with facilitating the hiring of Rhone as a welfare assistant. ${ }^{4} \mathrm{~A}$ former World War I officer, Oxley served as director of North Carolina's Bureau of Work among Negroes since 1925, when it was established through a grant from the Laura Spelman-Rockefeller Memorial Fund. This northern philanthropic organization supported the bureau as part of the state's Board of Charities and Public Welfare until July I, I93I, when the North Carolina General Assembly appropriated funds and took full financial responsibility for its operation. ${ }^{5}$ Oxley, who served until March 1934, often referred to the effort he led as a "division" of the state board. ${ }^{6}$ His successor, William R. Johnson, was more apt to refer to it as a "unit." Johnson's references to himself as a "consultant" and "field agent" suggest that he lacked a separate division or bureau to direct. ${ }^{8} \mathrm{John}$ R. Larkins, who began in September 1942 after Johnson resigned in March of that year, also favored the terms "unit" and "consultant."

This article refers to Oxley, Johnson, and Larkins as "leaders" or "heads" of the "unit." The first two terms reflect the fact that the position was a focal point for efforts to provide social welfare services to African Americans in the

3. Kimberly Johnson, Reforming fim Crow: Southern Politics and State in the Age Before Brown (New York, 20I0), 29-30.

4. Rev. Robert Isaiah Johnson to R.W. Miles, March 29, I926, folder I, Correspondence, I922-I929, North Carolina Commission on Interracial Cooperation Records, I922-I974 \#03823, SHC.

5. N. Yolanda Burwell, "Lawrence Oxley and Locality Development: Black Self-Help in North Carolina 1925-1928," in African American Community Practice Models: Historical and Contemporary Responses, ed. Iris Carlton-LaNey and N. Yolanda Burwell (New York, I996), 53; press release, "For Immediate Release," July IO, I93I, box 5, folder I4, BWAN.

6. Lawrence A. Oxley, "North Carolina State Board of Charities and Public Welfare, Division of Negro Welfare: For the Biennium Ending June 30, I934," box I0, Organization, HistoryDivision of Negro Welfare-Lawrence A. Oxley folder, BWAN.

7. William R. Johnson, "N.C. Negro Welfare Is Now Stressing Five-Point Program," Carolina Times (Durham, NC), December I0, I938, 8.

8. William R. Johnson to Julia Young Sessoms, July 15, 1937, box 23, Nash County folder, BWAN.

9. "John R. Larkins Named New Negro Consultant," Public Welfare Nerws 4, no. I2 (September I942), box II, Larkins, Personal 2 folder, BWAN. 
state, while the last term indicates that the effort they headed was part of a larger apparatus and not independent. The different terms for these leaders and what they led suggest the uncertain status of the unit. Its leaders nonetheless cited its existence as an example of the state's liberalism. Writing in the I940 Biennial Report of the Board of Charities and Public Welfare, for instance, William Johnson asserted that as an innovation "unparalleled in the nation," the unit had garnered attention from around the country. ${ }^{\text {10 }}$

This article examines the significance of the three unit leaders' attempts to increase and support the African American social workers employed by counties throughout the state. While social work scholars have examined Oxley's work in the bureau's first years, his successors' efforts have not been similarly explored. ${ }^{I I}$ In examining the history of the unit in the latter part of the I930s and I940s, this present study contributes to our understanding of the interracialism implied by the description of the representative responsibilities of Charlotte Rhone. In North Carolina and Georgia in the mid-I920s, social welfare programs for African Americans were initially funded by a mix of philanthropic investment and contributions from African Americans and whites. ${ }^{12}$ These programs were promoted as experiments to determine the benefit of providing formal social welfare efforts to black populations. They were also experiments in interracialism. Our study of them allows us to extend histories of this mode of interaction in time and into the state social welfare bureaucracy.

Informed by the ideas associated with William Chafe's Civilities and Civil Rights, which examined the force of white moderates' "unconscious" paternalism in mid-twentieth-century North Carolina, recent works have examined the practice and decline of "managed race relations" and "paternalistic interracialism" in the first half of the twentieth century. ${ }^{13}$ While in Virginia the "governmentalizing" of social welfare reform contributed to a decline in interracial

IO. William R. Johnson, Biennial Report of the North Carolina State Board of Charities and Public Welfare: fuly I, 1938 to fune 30, 1940 (Raleigh, NC, I940), I73.

II. Burwell, "Lawrence Oxley and Locality Development," and "Lawrence A. Oxley: Defining State Public Welfare among African Americans," in African American Leadership: An Empowerment Tradition in Social Welfare History, ed. by Iris B. Carlton-LaNey, (Washington, DC, 200I), 99-IIO; John L. Bell, "Lawrence Augustus Oxley: The Beginnings of Social Work among Blacks in North Carolina Counties," fournal of the Appalachian Studies Association 3 (I99I): 98-Io9.

I2. Sarah Wilkerson-Freeman, "The Creation of a Subversive Feminist Dominion: Interracialist Social Workers and the Georgia New Deal," fournal of Women's History I3, no. 4 (Winter 2002): 138 .

13. William Chafe, Civilities and Civil Rights: Greensboro, North Carolina and the Black Struggle for Freedom (New York, I980), 8; J. Douglas Smith, Managing White Supremacy: Race, Politics, and Citizenship in fim Crow Virginia (Chapel Hill, NC, 2002), 4; Clayton McClure Brooks, The Uplift Generation: Cooperation across the Color Line in Early Twentieth-Century Virginia (Charlottesville, VA, 2017), I70. 
paternalism during and after the I920s, in North Carolina the unit's mission preserved this mode of interaction. If reformers' personal influence was undermined by the transformation of "private benevolence into public Progressive reforms" in Virginia, in North Carolina efforts to hire black social workers and sustain their work bolstered interracial paternalism through the I940s. ${ }^{14}$ This study scrutinizes this neglected persistence of interracialism within the state's social welfare bureaucracy and demonstrates its relationship to the vocabulary of racial uplift.

The effort to employ and support black workers reflected the interplay between two "belief systems" that Kimberly Johnson identified as integral to "Jim Crow reform." The first held that the Jim Crow order was based on nearly immutable folkways. The second held that the state, assisted by social scientific knowledge, could alter those folkways. ${ }^{15}$ The use of the language of "racial uplift" by the leaders of the Unit of Work relied on the presumptions of the former belief system to accomplish goals informed by the latter. Historian Kevin Gaines has argued that the vocabulary of uplift in the early twentieth century "constituted a measure of ideological collusion with discriminatory ideologies and practices." 6 The language of racial uplift sought to "rehabilitate the image of black people through class distinctions" while ironically remaining tethered to "racial and gender hierarchy." "It It supported claims of leading African Americans that intraracial class differences demonstrated post-Emancipation development. ${ }^{18}$ What W.E.B. Du Bois referred to as the "'better class" " of African Americans in his sociological study The Philadelphia Negro (1899) had an obligation to improve the lives of others of their race. ${ }^{19}$ From the "civilizationist" perspective of many uplifters, this improvement would demonstrate African Americans' capability for cultural assimilation. ${ }^{20}$

Uplift vocabulary, with its emphasis on class distinctions, complemented interracialists' vision of elite-managed race relations. ${ }^{21}$ This study extends Clayton

I4. Brooks, Uplift Generation, 6.

I5. Johnson, Reforming fim Crow, 4I.

16. Kevin Gaines, "Black Americans' Uplift Ideology as ‘Civilizing Mission': Pauline E. Hopkins on Race and Imperialism," in Cultures of United States Imperialism, ed. Amy Kaplan and Donald E. Pease (Durham, NC, 1993), 450; Touré Reed, Not Alms but Opportunity: The Urban League and the Politics of Racial Uplift, 1910-1950 (Chapel Hill, NC, 2008), 6.

17. Kevin Gaines, Uplifting the Race: Black Leadership, Politics, and Culture in the Trwentieth Century (Chapel Hill, NC, 1996), xiii.

I8. Ibid., I65.

19. Ibid., 153. As historian Malinda Alaine Lindquist has noted, Du Bois turned away from the "heterosexist, capitalist, imperial orientation" associated with uplift ideology (Race, Social Science and the Crisis of Manbood, 1890-1970 [New York, 2012], 55).

20. Gaines, Uplifting the Race, 35 .

21. Brooks, Uplift Generation, I05. 
McClure Brooks's examination of the relationship between uplift and paternalistic interracialism in early-twentieth-century Virginia. ${ }^{22}$ Because "uplift" assumed the ability of leading African Americans to shape the behaviors of black populations, it was a central term in unit leaders' attempts to justify and increase black social workers' employment. If class distinctions were vital to uplift ideology, so was their traversal. ${ }^{23}$ That supposedly frictionless relationship allowed black social workers unique access to African American communities. Unit leaders argued for the value of these workers by focusing on the knowledge they could create. They claimed that African American workers could produce better information about their clients and about black communities in their counties.

Some African American social workers and sociologists during this period wielded knowledge about black lives and communities in the hopes of producing beneficial changes rather than making those communities more legible to white authorities. Social work scholar Iris Carlton-LaNey has demonstrated that some "pioneer" social workers of the I920s counseled colleagues to use their knowledge of their people's experiences to support the "cultural uniqueness of the group" rather than to insist on conformity. ${ }^{24}$ Historian Malinda Alaine Lindquist and sociologist Aldon D. Morris have each noted that W.E.B. $\mathrm{Du}$ Bois urged sociologists to create scientific knowledge that was meaningful to the communities under study and could "be utilized to engender social change." 25 However, unit leaders largely framed the knowledge that black social workers could bring to bear on their responsibilities as a way to help African Americans "adjust," in the words of unit leader John Larkins, "to the type of world in which they must live." 26

Despite being shaped by paternalistic interracialism, the Unit of Work outlasted its decline, as Larkins continued as consultant until I962. Its history thus additionally offers an opportunity to examine how those involved in social welfare and reform efforts navigated this changing landscape. By the mid-I940s, African Americans' growing willingness to call for an end to segregation and whites' fears of black militancy contributed to what Kimberly Johnson has referred to as the "exhaustion of biracial doctrine." Interracialism had previously facilitated Jim Crow reform. Its perceived shortcomings in the I940s impacted the unit's mission of increasing and supporting the employment of black

22. Ibid., 6.

23. Gaines, Uplifting the Race, I29.

24. Iris Carlton-LaNey, "African American Social Work Pioneers' Response to Need," Social Work 44, no. 4 (July 1999): 315.

25. Aldon D. Morris, The Scholar Denied: W.E.B. Du Bois and the Birth of Modern Sociology (Oakland, CA, 2015), I33; Lindquist, Race, Social Science and the Crisis of Manhood, 55.

26. John R. Larkins, "Social Work among Negroes in North Carolina," box 3, folder Io, BWAN. 
social workers. ${ }^{27}$ The scope of John Larkins's interactions with white members of the state social welfare bureaucracy narrowed over the course of the decade. At the same time, the language of uplift was less influential, as Larkins's descriptions of the value of black social workers emphasized their role in the provision of services. Absent were the prior appeals to their representative function in interracial negotiations and their role in collective uplift.

This article has four sections. The first examines the central place of interracialism in the establishment and initial years of the unit, when it was headed by Lawrence Oxley. The second examines the efforts of the second unit leader, William Johnson, to use state power to protect black social workers during the Great Depression in the context of the New Deal's shifting relief priorities. Johnson was unable to provide significant protection in North Carolina, in contrast to state social welfare workers in Georgia. His effort nonetheless illustrates the attempted use of state power to more significantly challenge white supremacist norms. The third examines John Larkins's attempts to encourage the employment of black social workers during World War II. The final section illustrates the changes that accompanied the decreasing trust in interracialism as a mode of interaction that could contain conflict within the confines of the Jim Crow order.

\section{UPLIFT AND INTERRACIALISM UNDER OXLEY}

African American social workers were central to the goals of community organization and provision of social welfare services. Securing these workers' employment in the quarter-century following the founding of the unit meant not just convincing county superintendents of public welfare of the benefits of their work. In collaboration with local African Americans, unit leaders also had to gain the support of the county welfare board that advised the superintendent as well as of the county commissioners who appropriated funds for the worker's salary. In seeking to make the unit an effective instrument for the improvement of African Americans' lives and opportunities, Oxley and his successors challenged whites' expectations about the roles of African Americans in local government and in social welfare.

Oxley imagined this project to be a collective endeavor. As historian N. Yolanda Burwell has noted, Oxley demonstrated the "self-help and empowerment tradition" within African Americans' social work philosophy. ${ }^{28}$ After World War I he served as an assistant industrial secretary for the YMCA in Harlem and taught social sciences at the black Saint Augustine's College in

27. Johnson, Reforming fim Crow, 237.

28. Burwell, "Lawrence A. Oxley," 99. 
North Carolina. Oxley emphasized in the Special Bulletin issued by the state board at the end of the unit's second year that African Americans had to take charge of the creation of a social welfare program. ${ }^{29}$ Rather than calling simply for individual responsibility, he suggested that self-help encompassed collective efforts. ${ }^{3 \circ}$ The projects, Oxley wrote, had to proceed with African Americans "fully understanding and assuming in large measure responsibility as individuals, and as a racial group, in solving their own problems." The unit and the social workers whose hiring it facilitated would help communities organize what he termed their collective "social forces." ${ }^{\text {I }}$ This process of organization would help to modernize supposedly isolated folk communities. ${ }^{32}$ Oxley's message about the value of social work relied on a sociological perspective similar to that of W.E.B. Du Bois. It recognized African American communities' capability to "develop a creative community" and "agency-laden social institutions." 33 Social workers were to guide this process. Oxley thereby emphasized the desire for "self-determination" associated with the post-World War I New Negro movement, although in the South the autonomy advocated by those associated with this movement was not as easily achieved. ${ }^{34}$ Interracialism necessarily impinged on this desire. As historian Clayton McClure Brooks has pointed out, it provided a means for whites to "resolve this inherent discrepancy" between their claims about the equal and separate entities that segregation purportedly created and their desire to exert control over African American spaces. ${ }^{35}$

Although the Laura Spelman-Rockefeller Memorial Fund supported the unit, local African Americans were initially required to subsidize the employment of black social workers. This condition may have contributed to those workers' assumed representative function. Their employment was a function of collective effort. African Americans were expected to subsidize the employment of black social workers as a demonstration of their commitment to social work. The unit began its organization in Wake County. The state commissioner of

29. Lawrence A. Oxley, North Carolina's Social Welfare Program for Negroes, Special Bulletin 8 (Raleigh, NC, I926), II, North Carolina Collection, Wilson Library, University of North Carolina at Chapel Hill (hereafter cited as NCC).

30. Carlton-LaNey, “African American Social Work Pioneers' Response to Need,” 3I2.

3I. Lawrence A. Oxley, "A Resume of Five Years' Effort in the Field of Public Welfare Work among Negroes in North Carolina, -With Outline of Some Results, and Limited Objectives," box I5, General Correspondence-R I925-I945 folder, BWAN.

32. John H. Stanfield II, Historical Foundations of Black Reflective Sociology (Walnut Creek, CA, 20II), I65-66.

33. Aldon D. Morris, "Sociology of Race and W.E.B. DuBois: The Path Not Taken," in Sociology in America, ed. Craig Calhoun (Chicago, 2007), 5 I6.

34. Leslie Brown, Upbuilding Black Durbam: Gender, Class, and Black Community Development in the fim Crow South (Chapel Hill, NC, 2008), II4.

35. Brooks, Uplift Generation, 40. 
public welfare, Kate Burr Johnson, appointed a countywide welfare committee in Wake County consisting of five African Americans. ${ }^{36}$ Smaller welfare committees were established in nineteen townships in the county as well. ${ }^{37}$ In order to raise money for the salary of an African American worker, the committees assigned each African American organization in the county a portion of the proposed budget to raise. By the end of February 1925, about two months into the program, three meetings had been held in the county, with an average of 600 people in attendance..$^{38}$ The initial effort raised $\$ 1,400$ of the goal of $\$ 1,500$, with about $\$ 900$ collected. The county superintendent would disperse the collected money to pay the worker's salary (fig. I). ${ }^{39}$

The employment of African American social workers indicated some amount of white authorities' acquiescence to this arrangement. That African Americans themselves raised the funds for the salary of these workers most likely influenced whites' consent. Discussing organizing plans in Wilson County in I928, Oxley advised that African Americans' own fundraising was important for convincing white officials. He recommended that the principal of an African American high school there ascertain what portion of the initial year's salary African Americans could themselves raise before proposing anything to county authorities. ${ }^{\circ}$ County organizing proved successful in raising funds and providing impetus for social workers. At the end of 1930, by Oxley's accounting African Americans had contributed nearly half of the \$3I,I80 expended. ${ }^{4 \mathrm{I}}$ Only one African American social worker was employed by a county public welfare department at the beginning of Oxley's work. ${ }^{42}$ There were twenty-six trained workers in the employ of the state's counties or cities by the end of $1930 .{ }^{43}$ By May I933, there were about forty-eight, according to Charities and Public Welfare commissioner Annie Bost, who succeeded Kate Burr Johnson in 1930.44

Unit leaders' utilization of the vocabulary of "racial uplift" shaped their attempts to convince whites that the unit's mission was compatible with paternalistic interracialism. Oxley and subsequent unit leaders emphasized the

36. Lawrence A. Oxley to W. C. Jackson, February 23, I925, box I4, Gen Corr J 1925-I944 folder, BWAN.

37. Oxley, North Carolina's Social Welfare Program, 20, NCC.

38. Lawrence A. Oxley to W. C. Jackson, February 23, I925.

39. Oxley, North Carolina's Social Welfare Program, I8-I9, NCC.

40. Lawrence A. Oxley to W.H.A. [William Henry Alexander] Howard, February 22, I928, box 24, Wilson County folder, BWAN.

4I. Oxley, "A Resume of Five Years' Effort."

42. Yolanda N. Burwell, "North Carolina Public Welfare Institutes for Negroes I926-I946," fournal of Sociology E Social Welfare 2I, no. I (March I994): 56.

43. "Raleigh, N.C.-May 27, I93I-For Immediate Release," 2, box 5, folder I4, BWAN.

44. "Minutes of the Meeting of the Negro Advisory Committee to the State Board of Charities and Public Welfare, Held during the Eight Annual Public Welfare Institute, May I-2, I933," box 30, Minutes of the Negro Adv. Comm., I927-I933 folder, BWAN. 


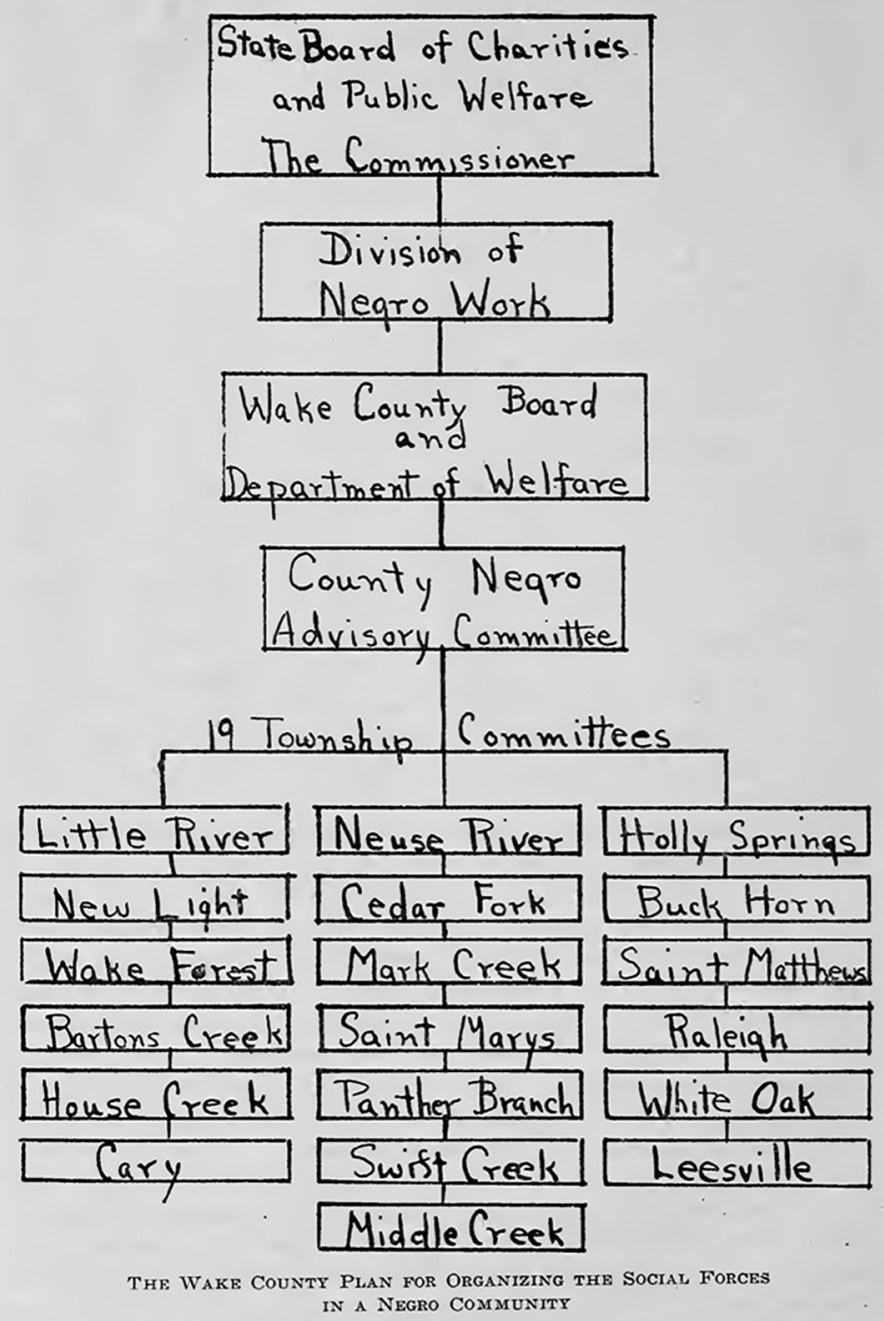

Figure I. From the North Carolina State Board of Charities and Public Welfare's Special Bulletin no. 8, "North Carolina's Social Welfare Program for Negroes," 20. The University of North Carolina Louis Round Wilson Library. The image shows the Division of Work's place in the structure of the State Board of Charities and Public Welfare as well as the organization of Wake County for the social welfare program. Color version available as an online enhancement. 
responsibility of educated African Americans, calling whites' attention to class stratification as a means of advancing their claims to both leadership and equitable treatment. In the 1926 Special Bulletin, Oxley noted that public welfare for African Americans would "come about through education and the efforts of the trained leaders of the race for their poorer and less intelligent fellows." In addition to endorsing a vision of reform that valorized intraracial class differences, Oxley emphasized the blameworthiness of poorer African Americans: "Many Negroes of the lower class, whatever their ability to pay for houses, do not keep their homes in decent condition. There is a slothfulness, an ignorance, and a dreadful carelessness among them." 45 Oxley's classist message reflected the shift away from biologism in the I920 s toward an examination of immediate environmental conditions associated with the ongoing professionalization of social work. ${ }^{46}$ The report in the bulletin presented the unit as intervening where people had supposedly been "handicapped by bad traditional environmental influences." 47

Central among those influences was the home, which was central to uplift ideology as a site for cultural assimilation..$^{4}$ In front of a mixed audience in Gastonia during its second year, Oxley similarly told of his personal intervention to rescue a twelve-year-old boy on the cusp of criminality, not only from illegal confinement in jail but also from an unfit mother who kept an indecent home. To encourage his audience, he imagined the value of a health officer, who would "go into the homes of our people and urge them into better living, better sanitary conditions; into making the home what it should be," which would have the result of "making better citizens." 49 Oxley's description of the poorer African Americans also may have served to reassure whites for whom the establishment of a unit of public welfare for African Americans presented a threat to white supremacy. By stating in the bulletin that "hundreds" of African Americans currently living in "filthy houses" were "able to live in cleaner and better" homes, the director suggested that individual adjustment and moral training was necessary rather than any systemic action..$^{\circ}$

In the same year that his report in the bulletin appeared, Oxley claimed that the state's white authorities had collectively accepted the premise of uplift: whites would recognize and accept African American leaders' demonstration of worth. He thus praised the state for perceiving "that the truly educated

45. Oxley, North Carolina's Social Welfare Program, II-I3, NCC.

46. Joyce M. Bell, The Black Power Movement and American Social Work (New York, 20I4), 72.

47. Oxley, North Carolina's Social Welfare Program, II, NCC.

48. Gaines, Uplifting the Race, 78.

49. E. M. Foley, "Excerpts from the Address of Lt. L.A. Oxley, Director, Bureau of Work among Negroes," March 7, I926, box 23.I, Gastonia, NC I925-1930 folder, BWAN.

50. Oxley, North Carolina's Social Welfare Program, II-I3, NCC. 
Negro is not a dangerous character." $5^{\mathrm{I}}$ Despite this claim, Oxley recognized that whites continued to perceive black social workers' status as a state employee with a claim to authority as a threat to white supremacy. His own experience confirmed this. About one year after the unit's establishment, Oxley made a "formal complaint" to W. E. Hawkins at the state highway commission. While returning in a two-car caravan to Raleigh from the unit's 1926 Public Welfare Institute for African American social workers, Oxley's party passed a parked state highway truck that was obstructing their lane. Oxley's car passed on the left, but when the trailing car attempted to do likewise it collided with an oncoming car. Oxley stopped so that he and his passengers could give assistance to those who were hurt, including "one of the white ladies [who] was thrown from the car." While this was happening, the driver of the parked state highway truck approached "and using profane language of the worst kind ordered our party to move the car," which was blocking the truck's path. By his own account Oxley informed the irate driver that he would move the car when "the injured had been cared for." As agitated as the abusive driver was, he only became more so when Oxley "told him of [his] official position with the State." Upon hearing this, the driver "grew more vehement and threatened [him] with a crowbar." Likely mindful that his account might be doubted, Oxley offered to provide the names of witnesses to vouch for his report..$^{2}$

Oxley called attention to the white driver's anger that his official position engendered as well as his own performance of bourgeois self-control, drawing an implicit contrast between the two. In a subsequent letter to Hawkins, Oxley clarified what he saw as the importance of the event. The driver's actions could potentially have led to a larger conflict had Oxley not possessed the necessary self-control, which he attributed to the preparation he received in the armed forces. Had it been "some of the lawless Negroes that I meet each week in the many prison camps of the State," the situation might have grievously escalated. ${ }^{53}$ Oxley thus engaged in elite self-presentation, employing the contrived negative image of lower-class African Americans who lacked the skill of selfcontrol, much as did the driver of the state vehicle.

Because of white resentment, the employment of individual African American social workers was a product of carefully orchestrated interracialism. There were discussions between Oxley, white county welfare officials, and leading blacks and whites in the county. For instance, in Durham in 1925, Superintendent Stanley and his welfare board asked Oxley to research more thoroughly several applicants for the position of assistant. The eventual choice, Nan Allen,

5I. Foley, "Excerpts from the Address of Lt. L.A. Oxley."

52. Lawrence A. Oxley to W.E. Hawkins, January 19, 1926, box I4, Gen Corr H-I925-1945 folder, BWAN.

53. Lawrence A. Oxley to W.E. Hawkins, January 30, 1926, box I4, Gen Corr H-1925-1945 folder, BWAN. 
was a product of consultation between Oxley and the superintendent, the board, and "representative" African Americans in Durham. ${ }^{54}$ County superintendents would later acquire even greater decision-making power over the hiring of black workers after the state took responsibility for funding social welfare work for African Americans in I93I.

Oxley also put the onus on black social workers to adhere to norms of Jim Crow in their relations with white coworkers and supervisors. In his report to Commissioner Johnson dated June I2, 1925, Oxley criticized the early African American social welfare situation in Greensboro. The African American assistant, M. E. Gilkerson, who was from Ohio, was "finding difficulty adjusting herself to conditions" in Greensboro. Gilkerson was unhappy and had informed the superintendent of her intention to resign if he did not agree to particular alterations. Oxley considered it the worker's responsibility to adjust herself to conditions as she found them. Although he conceded that baseless "racial fears" possessed the superintendent, circumstances would get better if she "could be made to realize that our personal likes and dislikes are small factors in a program of service, and that there are many matters it is wiser not to discuss." Oxley translated this conflict into personal views, while alluding more broadly to the requirements of whites' expectations. The burden, he suggested, was on Gilkerson, as she was the one in his eyes threatening to introduce "the race question or the matter of race relationships." Doing so would only undermine the public welfare project. ${ }^{55}$ In this case, Oxley placed the blame on the workers themselves for supposedly introducing issues of race if they appeared to question Jim Crow norms.

Oxley at times assured whites of female workers' humility, as they would not, in Oxley's mind, insist upon the marks of respect that had caused interracial efforts in Virginia in the 1920 s to fall into disrepute..$^{56}$ Writing to a member of the County Board of Commissioners in Gastonia, Oxley assured him that the superintendent of the African American County Hospital, Mercie D. Wheeler, "has never demanded that she be called 'Miss." As was the case in other times, the geographical background of the worker became part of the conversation. She was from South Carolina and received her education in North Carolina, which meant that she could "be trusted not to raise any personal issue of race," which in

54. Oxley, "Bureau of Work among Negroes Special Report,” June I2, I925, I, Commissioner's Office Subject Files I89I-I952, Interracial Cooperation, I919-I949 Box, Negro Bureau-Reports of organization work-L. A. Oxley, Director, I925 folder, Department of Social Services, North Carolina State Archives, Raleigh. This report is also quoted in Jeffrey J. Crow, Paul D. Escott, and Flora J. Hatley Wadelington, A History of African Americans in North Carolina (Raleigh, NC, I992), I38.

55. Oxley, "Bureau of Work among Negroes Special Report," June I2, I925, I.

56. Brooks, Uplift Generation, I9I. 
the end would only harm the hospital. ${ }^{57}$ Her own forbearance notwithstanding, Oxley stated his belief to the county commissioner that Wheeler should be referred to as superintendent due to her education as well as her "character." 58

While Oxley hoped workers would not violate Jim Crow etiquette, he also tried to help African Americans within the state bureaucracy to exercise authority. He at times argued that blacks should not abide unequal interracial work relationships. In his first year on the job, he and the white director of the Division of Institutions for the North Carolina State Board of Charities and Public Welfare, the future social work scholar Roy M. Brown, advocated for greater autonomy for the African American superintendent of Morrison Training School. Brown and Oxley submitted a report based on their visit to Morrison, a reform school for African American male youth meant to provide an industrial education. The report called attention to the "friction from the beginning" of the institution between Superintendent L. L. Boyd and J. S. Braswell, the institution's white business manager. The report was sympathetic to the superintendent, who "naturally and correctly" believed himself to be the actual rather than the titular leader of the school. The report identified Braswell as the party who wrongly believed himself to hold authority. The report suggested that Braswell sought to establish superiority over Boyd, adopting "an attitude that must be very irritating to a college-bred man" like Boyd, who had attended Tuskegee Institute and Oberlin College. ${ }^{59}$ The report called for power to be unequivocally placed in the latter's hands. ${ }^{60}$ Considering the limited funds the state was willing to provide the institution, the report made an economic argument for removing Braswell and his spouse, who also drew a salary as bookkeeper. These were in effect positions they fulfilled as side occupations despite drawing a collective salary of $\$ \mathrm{I}, 800$. This was an amount equal to that of $\mathrm{Su}-$ perintendent Boyd, whose own spouse worked at the institution without compensation. ${ }^{61}$ As historian Annette Louise Bickford noted, the state did not provide sufficient funds for the success of Morrison and did not provide for the safety of the children confined there. ${ }^{62}$ Nonetheless, this account illustrates how early in its history Oxley, in his own interracial work with Roy Brown, made efforts to provide Boyd with authority while seeking to remove whites who undermined that authority.

57. Lawrence A. Oxley to John L. Beal, January 26, I927, I, box 23.I, Gastonia, NC I925-I930 folder, BWAN.

58. Lawrence A. Oxley to John L. Beal, January 26, I927, 2.

59. Roy M. Brown and Lawrence A. Oxley, "Morrison Training School: Visited June 22, 1925," 2, box 30, Morrison Training School, Hoffman, NC, I925-194I folder, BWAN.

6o. Brown and Oxley, "Morrison Training School," 3.

6I. Ibid., 3-4.

62. Annette Louise Bickford, Southern Mercy: Empire and American Civilization in fuvenile Reform, I890-I944 (Toronto, 20I6), I58. 


\section{EFFORTS TO RETAIN AFRICAN AMERICAN SOCIAL WORKERS DURING THE GREAT DEPRESSION AND NEW DEAL}

As was the case with other leading African Americans in the South who advocated the employment of black social workers during the New Deal era, Oxley believed that the placement of African Americans in social welfare positions was necessary to provide equitable social services and relief. ${ }^{63}$ His experiences as coordinator of relief activities for African Americans in the state and as head of the Unit of Work appeared to have only made him more confident of this necessity. The enactment of relief programs during the Great Depression such as the Federal Emergency Relief Administration offered the possibility of expanded employment of black social workers. Shortly after Franklin Roosevelt's first inauguration, Oxley wrote to the Republican US House Representative Oscar DePriest, an African American from Chicago, to express his concerns about the dispersal of relief funds. Oxley had already participated in the distribution of five million dollars from the Reconstruction Finance Corporation. $\mathrm{He}$ stated his conviction that the provision of social welfare and relief services to the African American public could only be provided by "trained, intelligent" black workers on "the staffs of local relief agencies." Oxley defined his mission as the placement of "such Negro leaders in strategic places" in North Carolina as necessary to protect African Americans' interests, a goal he informed DePriest he hoped to pursue as part of the federal Department of Labor. ${ }^{64}$

The expansion of government relief efforts had conflicting effects on the employment of African American workers. In the case of Atlanta, New Deal relief efforts resulted in an increase in the number of black social workers. This increase, however, was threatened by mid-decade due to changing relief priorities. Workers in both Georgia and North Carolina anticipated that the Works Progress Administration's (WPA) assumption of responsibility for relief from the Federal Emergency Relief Administration (FERA) meant dimmer employment prospects. The WPA's focus on "large-scale public works" rather than public welfare made social workers' continued employment precarious. ${ }^{65} \mathrm{Ox}$ ley himself would not have to address this uncertainty. By April of 1934, Oxley had begun work for the US Department of Labor as a commissioner of conciliation, in time becoming a member of Roosevelt's "Black Cabinet." 66 In Georgia, Gay Bolling Shepperson, committed to inclusion of African Americans in the administration of social welfare, gained control over WPA relief

63. Karen Ferguson, Black Politics in New Deal Atlanta (Chapel Hill, NC, 2002), 97.

64. Lawrence A. Oxley to Oscar DePriest, April 8, 1933, box I4, General Correspondence-D 1925-I943 folder, BWAN.

65. Ferguson, Black Politics, 98.

66. Brown, Upbuilding Black Durbam, 292. 
funds, wresting control from Georgia governor Eugene Talmadge. ${ }^{67}$ As a consequence, many black social workers discreetly returned to their positions after having been earlier dismissed. ${ }^{68}$ This was particularly important, since, as social work expert Forrester Washington noted in 1934, social workers were the exception to the disregard demonstrated by relief programs for African Americans "above the lowest socio-economic class." ${ }^{69}$ In North Carolina, however, this return did not occur, and the number of black social workers declined dramatically. Much as Forrester Washington suggested that social workers "assume an active role in social welfare systems' development," Oxley's successor William Randolph Johnson pressed for changes in the rules that governed the administration of social welfare. ${ }^{70}$ These changes were meant to ensure proportional representation of black social workers, taking the question of whether or not to employ them out of the hands of many county superintendents. This demonstrates how the inability to retain workers led to the unit leader's formulation of strategies to more forcefully use state power, a solution outside the confines of interracialism.

William Johnson had served as a probation officer and welfare worker in Richmond, Virginia, as well as pastor at Central Baptist Church in Norfolk. Johnson, a native of North Carolina, graduated from Virginia Union College in Richmond before gaining an education in social work in New York. ${ }^{7 \mathrm{I}}$ One year into his tenure, Johnson wrote Bost about his concerns regarding the employment of black social workers in the state, which he confessed "weighed heavily upon my mind." FERA had taken responsibility for funding most of those workers. This meant that far fewer were actually supported by the counties. It was not clear whether the county welfare departments would hire those federal relief workers, who were concerned about their future employment. Johnson stated that "the Negro group is hopeful that every effort will be made in persuading the counties to reemploy these persons." Johnson wrote Bost hoping for clarity, as he could not "answer any of these questions." 72

Several of those questions had come from C. C. Spaulding, president of the North Carolina Mutual Life Insurance Company, the prominent African American insurance company that helped shape African American leadership

67. Wilkerson-Freeman, "Creation of a Subversive Feminist Dominion," I32.

68. Ferguson, Black Politics, 92

69. Forrester B. Washington, "The Negro and Relief," in Proceedings of the National Conference of Social Work, 6Ist Annual Meeting (Kansas City, MO, May 20-26, I934), I88.

70. Frederica H. Barrow, "Forrester Blanchard Washington and His Advocacy for African Americans in the New Deal," Social Work 52, no. 3 (July 2007): 207.

7I. "New Negro Field Agent Succeeds Lieut. Oxley," Beaufort (NC) News, April 5, 1934, 6.

72. William R. Johnson to Annie Bost, July 27, 1935, box 28, Memorandum from Bost, Mrs. W.T. Commissioner I937-I945 folder, BWAN. 
in Durham. ${ }^{73}$ Spaulding alerted Johnson that Willie A. Smith in Smithfield was being let go despite serving admirably as a social worker. Spaulding hoped Johnson would induce authorities in Smithfield to reconsider. ${ }^{74}$ Several months later Johnson received a second request from a citizens committee, which Spaulding chaired. The committee hoped that Johnson would continue to call Bost's attention to the gradual elimination of African Americans from local relief structures. At the insistence of their supervisors, many of these workers had purchased automobiles. Now those discharged workers "find themselves not only without employment, but also with the added expense" of installment payments. ${ }^{75} \mathrm{By}$ May 1936, Johnson noted that he received questions nearly every day about placing black workers in the counties with substantial black populations. ${ }^{76}$

The decline in the number of workers was dramatic. A report on the unit from I936, very likely written by Johnson, stated that two years earlier there were around eighty-two African Americans employed in social work in the state. At the time the report was written, that number had fallen to "only eight or nine." A draft of this report asserted that no "provisions for a social service department" had accompanied the transition from the FERA to the WPA. A later draft's cosmetic revision of this evaluation to a "limited" provision for social services did not alter the overall assessment that the replacement of one relief agency with another had indeed proven disastrous for African American social workers. ${ }^{77}$ In the first half of 1936 slight progress had been made in reversing this movement. However, of the few that the unit had been able to place, none served counties where African Americans made up a majority of the population. Although the earlier draft termed it "imperative" for counties to employ more African American workers, a revision removed this emphasis. ${ }^{78}$

As noted previously, the employment of African American workers was dependent on interracial discussions among the unit head, local leading blacks and whites, and white county officials. Johnson appealed for the employment of black social workers using the language of uplift and interracialism. The I936 report advocated the benefits of black social workers. First, their presence would improve the African American population through uplift. It "raise[d]

73. Brown, Upbuilding Black Durbam, II8.

74. C. C. Spaulding to William R. Johnson, July 2, I935, box 22, Johnston County folder, BWAN.

75. James T. Taylor to William R. Johnson, November I6, I935, box 22, Durham County folder, BWAN.

76. William R. Johnson to Bost, May 2, I936, box 28, Memorandum from Bost, Mrs. W.T. Commissioner 1937-I945 folder, BWAN.

77. "Work among Negroes," n.d., 3, box Io Organization, History-Division of Negro WelfareLawrence A Oxley folder, BWAN.

78. "Work among Negroes," n.d., 2. 
the morals" of clients "to have one of its own group" enter their houses and address their needs. Second, the report highlighted black workers' supposedly superior ability to create social knowledge about their clients. Those workers could produce social knowledge more readily and easily, as they "get closer to the homes of Negroes, thus giving to our welfare departments more definite information regarding the needs of these families." The report asserted that the social workers were "trusted by their own people."79 Johnson echoed social work experts like Forrester B. Washington and Gay Bolling Shepperson, who made similar arguments about the value of black social workers. ${ }^{80}$ The conviction that black social workers could easily gain access to the lives of their clients may also have reflected assumptions about intraracial relations shaped by uplift ideology. As several scholars have noted, relations between objects and subjects of uplift were often characterized by tension. Reform projects associated with the National Urban League in the I920s, for instance, prioritized and normalized middle-class perspectives. ${ }^{81}$ The unit's 1936 report, however, blurred possible tensions among African Americans by asserting that greater trust existed between black workers and their clients, which in turn allowed for the provision of better service and the generation of more precise knowledge.

William Johnson's approach placed black social workers in a mediating position. Guidelines circulated by the board that defined workers' responsibilities suggested some of the interracial work that black workers were called upon to perform when they mediated between the state's white social welfare bureaucracy and its African American clients. Workers produced knowledge about the client for the client's sake and for the state itself. This dual responsibility was recognized by the state's Board of Charities and Public Welfare. In I940 the state's Division of Public Assistance circulated to all county superintendents and members of case work staff an excerpt of Eva Abramson's "The Problem of Mechanics and Procedures," which it endorsed "as a well-defined statement of the case worker's responsibilities and tasks." ${ }^{82}$ These responsibilities included determining the eligibility of members of the public for assistance, the levels of assistance, and different programs that might assist individuals. Workers' appraisals of their clients were significant, as they set the duration and level of support, although this aid was dependent on the agreement of the worker's supervisor. Information included "essential social and financial data." The case

79. "Work among Negroes," n.d., 2.

80. Washington, "The Negro and Relief," I94; Wilkerson-Freeman, "Creation of a Subversive Feminist Dominion," I39.

8I. Reed, Not Alms but Opportunity, 43.

82. Document DPW-PA-4I, "Re: Excerpt from 'The Problem of Mechanics and Procedures' by Eva Abramson," August I4, I940, I, box 25, Public Assistance Division Director Nathan Yelton folder, BWAN. 
worker was to stay "alert to possibilities of rehabilitation" and advised to quickly stop aid when they judged circumstances no longer warranted it. ${ }^{83}$ The Division of Public Assistance expected regular and transparent transmittal of information, as workers had the additional responsibility of dictating information without delay regarding "significant developments in the relationship with the client." ${ }^{84}$ These responsibilities provided the outlines for these workers' relationships to their white supervisors.

Johnson appeared to become increasingly frustrated in the I930s and early I940s with the lack of progress in hiring African American social workers. He considered it his occupational duty to see that black social workers were hired by the different counties. ${ }^{85}$ In February 1936 he suggested to Commissioner Bost that all counties with a population that was at least 25 percent African American employ one worker, and that those with large cities employ two. ${ }^{86}$ He recommended that this be a statewide policy and not left up to individual counties. Unable to effect such a change in policy, Johnson represented it as a goal of the state board, stating in one letter to the Granville County superintendent that it was the "desire of the State Board of Charities and Public Welfare to place" black workers in counties with "large" black populations. ${ }^{87} \mathrm{John}$ son also publicly identified the goal of placing black workers in counties whose population was at least one-quarter African American as one of the unit's essential five objectives in a 1938 public statement in the black newspaper The Carolina Times. ${ }^{88}$ Johnson thus made uplift arguments while also hoping to effect the alteration of the political rules that required the person in his office to convince whites in each county to employ black social workers.

Johnson was not alone in seeking other means besides interracial cooperation to achieve the employment of greater numbers of African American social workers. In 1936 the North Carolina Committee on Negro Affairs organized in Durham. Members of its executive committee included C. C. Spaulding and James E. Shepard, president of the North Carolina College for Negroes. The committee hoped to increase the numbers of African Americans registered to vote. It also encouraged African American organizations throughout the state to affiliate with it, on order to "present a solid front." Combined with the

83. Document DPW-PA-4I, 2.

84. Document DPW-PA-4I, 2-3.

85. William R. Johnson to Julia Young Sessoms, July I5, 1937, box 23, Nash County folder, BWAN.

86. Johnson to Bost, February 3, I936, box 28, Memorandum from Bost, Mrs. W.T. Commissioner I937-I945 folder, BWAN.

87. Johnson to Lee C. Taylor, February 7, 1936, box 29, Granville County, 1929-1940 folder, BWAN.

88. William R. Johnson, “N.C. Negro Welfare Is Now Stressing Five-Point Program,” Carolina Times, December I0, I938, 8. 
prospective increase in black voters, this unified representation would provide greater influence in achieving the committee's goals, which included the placement of social workers "in all county and state institutions" and the protection of the social citizenship of their clients. ${ }^{89}$ Like this committee, Johnson looked to processes other than interracialism, such as elections, to increase the number of black workers.

Johnson was unsatisfied with the modest recovery in the number of African American social workers he oversaw in the late I930s. He counted thirteen black social workers employed in the state in 1936. He estimated that a minimum of sixty black county workers were needed. Johnson pointed out that there were no black workers in many of the counties where African Americans made up between 40 and 63 percent of the population..$^{9 \circ}$ In his biennial report of I938, Johnson was able to point to some additional hiring of African American workers. ${ }^{9 \mathrm{I}}$ After four additional hires in 1938 , Johnson could count a total of twenty-six African Americans social workers employed in fourteen counties. ${ }^{92}$ In I94I, Johnson's last full year as consultant, the number of public workers stood at twenty-seven. These included case workers, case aides, and probation officers. Johnson protested to Bost that "very little progress has been made" despite his attempts to persuade county authorities that black workers "can work better with" blacks. ${ }^{93}$

\section{INGREASING TENSIONS OVER INTERRAGIALISM DURING WORLD WAR II}

Similar to Oxley and Johnson, third unit head John R. Larkins attempted to blunt the persistent enmity focused on African American workers. $\mathrm{He}$ employed the vocabulary of uplift in providing an image of an African American community characterized by heroic class distinctions. In his second report published for the public in the 1944 Special Bulletin, Larkins asserted that the role

89. Department of Labor, US Employment Service, L. A. Oxley Files, Senior Racial Relations Specialist, State Reports, Alabama-West Virginia, "Prospectus of North Carolina Committee On Negro Affairs," March 15, 1936, in Conference for Black Social Workers in North Carolina, folder ooI398-oII-0632, December I, I937-February 28, 1938, in New Deal Agencies and Black America, ProQuest History Vault.

90. "Proceedings, Conference of the Division of Cooperation in Education and Race Relations," December 9, I936, II, box 26.2, NC State Dept. of Public Instruction, Mr. Trigg, Mr. Newbold folder, BWAN.

9I. "Biennial Report of Work among Negroes," n.d., box Io, Organization, History-Division of Negro Welfare-Lawrence A. Oxley folder, BWAN.

92. "Negro Social Work Staff Enlarged by Four New Members," n.d., box 4, News Releases and Communication Rereleases folder, BWAN.

93. Johnson to Bost, April I6, I94I, box 28, Memorandum from Bost, Mrs. W.T. Commissioner, I937-I945 folder, BWAN. 
of the "professional group" was to serve as "the voice of the masses" and to "set the standards and pace" for African Americans as a whole. This group occupied a "position of leadership and prestige." Larkins presented a frictionless relationship where less fortunate African Americans "usually attempt to imitate [the professional group] as much as possible." ${ }^{94}$ Larkins, who earned a master of social work degree from Atlanta University the year before he succeeded William Johnson in September I942, told Superintendent James Glover of Nashville that while white social workers were sufficient for relief, black workers would effect the rehabilitation of their clients. ${ }^{95}$ They would transform their clients into "assets" rather than "liabilities." 96 The social worker's worth was measured in terms of how she or he could correct the individual. The statement drew on a familiar understanding of social work that "located the social problem in the individual client." ${ }^{\prime 97}$ The statement suggested social workers' responsibility was to "counsel" rather than "advocate" for clients, which accorded with some workers' aspirations for professionalization. ${ }^{98}$

This understanding of the value of African American social workers was based on the kind of adjustments Larkins thought were necessary. He framed race as its own separate category of adjustment. He stated that African Americans were confronted with the necessity of making altogether three adjustments: the first was "that of race, second, social, and third, economic." Larkins thus asserted race required its own adjustment separate from other conditions of life, which trained social workers who were also African American could help the African American public to navigate. Larkins's justification for black social workers employed the vocabulary of race relations. This vocabulary presumed, as historian Barbara Fields has observed, "that race is a valid empirical datum." This supposition shifts the focus of efforts at social intervention "from the actions that constitute racism," including segregation, disfranchisement, and violence "to the traits that constitute race." "'०० Larkins's

94. John R. Larkins, The Negro Population of North Carolina: Social and Economic, Special Bulletin 23 (Raleigh, NC, I944), I8.

95. Larkins to Bost, “Conference with Mr. James A. Glover,” January 26, I943, I, box 5.5, folder I7, County Consultation Reports, BWAN.

96. Larkins to Bost, "Conference with Miss Ina V. Young," August 4, I943, I, box 5.5, folder I7, County Consultation Reports, BWAN.

97. Patricia Longermann and Gillian Niebrugge, “Thrice Told: Narratives of Sociology's Relation to Social Work," in Sociology in America, ed. Craig Calhoun (Chicago, 2007), 83.

98. Longermann and Niebrugge, "Thrice Told," 93; Bell, Black Power Movement, 72.

99. Larkins, "Social Work among Negroes," n.d., I.

Iоo. Barbara J. Fields, "Origins of the New South and the Negro Question," fournal of Southern History 67, no. 4 (November 200I): 8I2. Also see Michael Rudolph West, The Education of Booker T. Washington: American Democracy and the Idea of Race Relations (New York, 2006), I2-I4. 
formulation illustrates how African Americans during the Jim Crow period had to "accept race, the badge that racism assigns them," in their attempts to gain "remission of the attendant penalties."

Larkins communicated with superintendents throughout the state, seeking to encourage their employment of African American social workers. Superintendents who declined to do so provided a number of reasons related to rituals and practices of interracialism. One superintendent in 1943 recounted the memory of a previous social worker who requested that she be treated with respect when responding negatively to the possibility of employing another black worker. J. D. Pegram, responsible for public welfare in Lee County, recalled how the preceding worker "was a bad influence and did more harm than good. She did not know how to work in harmony with the whites." Among her socalled missteps was her request to be referred to with the honorific "Mrs." This professional worker's bold and defiant request violated the white supremacist practice of denying African American women the status and respect accorded womanhood..$^{103}$ Other superintendents refused Larkins by claiming that the physical accommodations in their social welfare departments would violate the spatial requirements of Jim Crow. ${ }^{104}$

Superintendents also denied the necessity for interracialism by disputing the premise, related to uplift ideology, that black workers could serve the African American public better than could white workers. They denied that black workers fulfilled a mediating role. Racial uplift supported interracialism; conversely, denying the former weakened the justification and diminished the opportunities for the latter. For instance, Granville County superintendent Lee C. Taylor dismissed Johnson's query regarding the hiring of an African American social worker by arguing that white workers already possessed the personal knowledge necessary to help black clients. ${ }^{105}$ Johnson's successor encountered a similar objection from the public welfare superintendent of Scotland County, E. F. Murray, who stated "his love for Negroes" and childhood "with them on the farm" to explain the lack of black social workers

IOI. Fields, "Origins of the New South," 8I8.

I02. John R. Larkins to Annie Bost, "Conference with Mr. J.D. Pegram, Superintendent Public Welfare, Sanford, N.C.,” August 6, I943, 2, box 5.5, County Consultation Reports folder, BWAN.

I03. Bickford, Southern Mercy, II8-II9.

I04. Larkins to Ellen Winston, "Conference with Mr. E. Farrell White Superintendent of Public Welfare, Concord, December I3, I944," December 20, I944, box 22, Cabarrus County folder, BWAN.

I05. Lee C. Taylor to Johnson, Feb. 21, I936, box 29, Granville County, I929-1940 folder, BWAN. 
despite the fact that African Americans made up 50.2 percent of the county population. ${ }^{106}$ Kate S. McLeod, superintendent of Robeson County, made a parallel point to Larkins. McLeod disagreed with Larkins's argument that black social workers "understand their people better" by virtue of their "common backgrounds and experiences." Disagreeing, McLeod instead pointed to "her early life and great love for" African Americans. ${ }^{107}$ From his own account, Larkins suggested that such justifications said more about McLeod's assumptions than about the quality of social welfare services provided African Americans. He responded to the superintendent by denying her claims to professional knowledge, as her "feelings [were] attitudes or maternalistic ideas." McLeod's professed regard for the race was "subjective not objective" and only applied to particular individuals. ${ }^{\text {108 }}$

To these justifications were added new ones during World War II. As has been documented elsewhere, interracialism became increasingly embattled during the war. Such attempts as the Durham Conference in 1942, which was meant to "resuscitate interracial dialogue," succeeded in weakening it further. The conference's reputedly moderate and cautious black leaders declared their "independence from interracial paternalism." "One year after the meeting, Durham itself was the site of one of the many race riots during the war. ${ }^{\text {Iro }}$ In 1944, Mecklenburg County superintendent Louise O. Neikirk noted the ill effects of the war. She attributed what Larkins termed "unduly strained" race relations in the city to the recently erected rubber factory, "which has brought a large number of ignorant" workers, both white and black, to the city." She blamed such developments for the recent "acute tension" regarding city buses. Wartime changes had disrupted supposedly previously harmonious arrangements.

Nevertheless, Neikirk communicated to Larkins her wish for the county to hire an African American man to replace the one who had left for employment in Brooklyn. She asked Larkins to help her "in securing this worker." Neikirk's advice illustrated the terms of paternalism. While suggesting to Larkins

Io6. Larkins to Bost, "Conference with Mr. E.F. Murray," December 23, I942, box 5.5 folder I7, County Consultation Reports, BWAN.

I07. Larkins to Bost, "Conference with Mrs. Kate S. McLeod," January 20, I943, I, box 5.5, folder I7, County Consultation Reports, BWAN.

I08. Larkins to Bost, “Conference with Mrs. Kate S. McLeod,” January 20, I943, I, box 5.5, folder I7, County Consultation Reports, BWAN.

I09. Johnson, Reforming fim Crow, 234.

IIo. Jerry Gershenhorn, Louis Austin and the Carolina Times: A Life in the Long Black Freedom Struggle (Chapel Hill, NC, 20I8), 75-76.

III. Larkins to Ellen Winston, "Conference with Mrs. Louise O. Neikirk," December 20, I944, box 23, Mecklenburg County folder, BWAN. 
that African Americans not "use the term equality until they have improved their social and economic conditions," Neikrik recommended that Larkins "should solicit support, cooperation, tolerance, and liberal treatment from both" whites and African Americans. ${ }^{\text {II2 }}$ Neikirk thus advocated that Larkins continue to pursue a strategy of deferential interracialism, allowing whites to perform their preferred paternalistic roles and encouraging African Americans not to raise questions of equality.

Other county superintendents, however, cited conditions fostered by the war for refusing to employ black social workers. The Edgecombe County superintendent named duplication of travel as a reason why the hiring of a black worker was "difficult." This duplication of travel was necessitated by the insistence that black case workers could not work with white clients, although white case workers regularly worked with black clients. This was a particular obstacle due to wartime's gasoline rationing. Given that constraint, the racial limitations that whites placed on black workers' caseloads became another justification for not hiring them. ${ }^{\mathrm{II}}$ Superintendents in multiple communities throughout the state also identified the wartime shortage of African American domestic servants as a source of tension. According to superintendent Lora P. Wilkie of Warrenton in I943, perturbed whites believed that the public welfare department was responsible. She reported receiving "numerous criticisms ... due to this acute shortage of servants.” In refusing Larkins's suggestion that she hire a black worker, Wilkie believed that such a course of action "would only aggravate a bad situation."

Given the rising wartime tensions, whites may have become increasingly quick to take offense over African Americans' perceived transgressions of interracial paternalism. African Americans' pursuit of the goal of state investment in black social workers always risked angering county superintendents and other white authorities. The effort more often than not called for great care. In a 1943 conversation with Larkins, the African American farm agent S. T. Brooks evaluated the most recent unsuccessful attempt to do so in Robeson County. He identified two errors that illustrated the intertwined etiquette of Jim Crow and the social welfare structure. Brooks noted that the group of African Americans met with the county commissioners, who would have to appropriate funds for any worker. However, the group had not conferred with the

II2. "September I5, I944," "Mrs. Louise O. Neikirk, Superintendent of Public Welfare, Charlotte, N.C."

II3. Larkins to Bost, "Re: Integration of Negroes in Social Work Program Edgecombe County, Tarboro, N.C.," May 27, I943, I, box 5.5, folder I7, County Consultation Reports, BWAN.

II4. Larkins to Bost, “Conference with Mrs. Lora P. Wilkie," May 2I, I943, I, box 5.5, folder I7, County Consultation Reports, BWAN. 
superintendent before meeting the county authorities. The second misstep was that one committee member "talked too much and antagonized" the county commissioners and superintendent. ${ }^{\mathrm{II}}$

Unit leaders could also draw the ire of superintendents. The superintendent of Rockingham County, Mrs. John Lee Wilson, blamed Larkins in 1943 for supposedly stirring up African Americans. Wilson thought that Larkins's visit "stimulated the local Negroes to visit County Commissioners and put pressure on her to secure" a black worker. Larkins acknowledged that he made a mistake by visiting the county at the end of May 1943 without "contacting or clearing" the visit with the superintendent beforehand. However, he disputed the accusation that he had inspired the local group's desire for a black worker, since the group had made repeated requests in the past to the superintendent. ${ }^{\mathrm{II}}$ He was not responsible for their frustration with Superintendent Wilson, who they believed gave "them the run-around with niceness," as he had reported earlier in May 1943 ${ }^{117}$ In his telling, he tried only to advise them regarding the "the proper way to approach" the superintendent in order to be successful and in fact had lessened the pressure the group had planned to apply. He did allow, however, that "the attempt to place Negro workers is one of the sore spot or dangers of the program." ${ }^{\prime 18}$ After this episode, Larkins advised African American farm agent R. L. Hannon to not move forward without speaking to him, as the recent controversy had left the unit head "in a precarious position."

\section{NEW LIMITS ON INTERRACIALISM}

African Americans' impatience with undemocratic structures continued after the war. Like elsewhere in the South, in North Carolina blacks organized and sought political power. Greensboro and Winston-Salem were sites for a "new black presence in politics" as a result of "aggressive candidacies for office." As William Chafe has observed, these efforts "occurred in the face of white terrorism." White authorities' concerns about African Americans' organizing

II5. Larkins to Bost, “Conference with Mr. S.T. Brooks," January 20, I943, I, box 5.5, folder I7, County Consultation Reports, BWAN.

II6. Larkins to Bost, "Conference with Mr. S.J. Hawkins, concerning duties of Consultant and visits to Rockingham County,” June I4, I943, I, box 5.5, folder I7, County Consultation Reports, BWAN.

II7. Larkins to Bost, “Conference with Mrs. John Lee Wilson,” May I2, I943, 2, box 5.5, folder I7, County Consultation Reports, BWAN.

II8. Larkins to Bost, "Conference with Mr. S.J. Hawkins," I.

II9. Larkins to R.L. Hannon, June 15, I943, box 23, Rockingham County 1943-45 folder, BWAN.

I20. William H. Chafe, "Race in America: The Ultimate Test of Liberalism," in The Achievement of American Liberalism, ed. William H. Chafe (New York, 2003), I64. 
efforts may have contributed to a change in the unit's orientation to paternalistic interracialism. There was a decline in Larkins's opportunities to initiate conversations with county superintendents regarding the employment of social workers and to advise local African Americans on such matters. In addition, Larkins emphasized the individual service that workers provided to their clients. Absent were the representative and interracial functions highlighted in earlier descriptions.

These changes began shortly after Ellen Winston took over as commissioner of public welfare in June 1944, succeeding Annie Bost. The new commissioner, who earned her $\mathrm{PhD}$ in sociology from the University of Chicago in 1930, emphasized limitations on the ability of Larkins to press for black workers to be hired in the counties of the state. In a 1974 oral history, Winston remembered that the department was "encouraging counties to have more black workers on their staffs and that sort of thing." She portrayed public welfare as unconcerned with "the whole question of racial strife and attitudes." ${ }^{212}$ Indeed, Winston took steps to ensure that the unit kept its distance from such issues and restricted Larkins's ability to engage superintendents on the issue of black workers. ${ }^{\text {I22 }}$ Two months into her service as commissioner, Winston noted that the supervisor of personnel and county organization, Mrs. W. B Aycock, would inform Larkins when black workers were hired by the county superintendents. That was the "correct channel for handling this matter." Larkins would be updated as to the location and number of workers only. Furthermore, Winston stated that Larkins should wait until a superintendent specifically asked for "consultant service." The superintendent of Hoke County, Mrs. C. H. Giles, sought no such assistance at the present time; therefore Larkins "should not go into that county unless specifically invited by Mrs. Giles.” Larkins would not initiate action or visits. Instead, field staff would send him memoranda if they thought a "particular situation involving" African Americans merited his consideration. ${ }^{\text {I23 }}$ Two years later, during a meeting that she summed up afterward in a memorandum, Winston explicitly defined "finding jobs for Negroes, whether in social work or in other fields," as being outside the bounds of his work. ${ }^{124}$ This condition removed what each of the unit leaders had considered a central responsibility of their position.

I2I. Oral history interview (G-0064) with Ellen Black Winston, December 2, 1974, Southern Oral History Program Collection (\#4007), SHC.

I22. Eileen Boris, "Ellen Black Winston: Social Science for Social Welfare," in North Carolina Women: Their Lives and Times, ed. Michele Gillespie and Sally G. McMillen (Athens, GA, 20I5), 256.

I23. Winston to Larkins, August 19, I944, box 9, Dr. Ellen Winston-Com of Pub. Welfare-2 folder, BWAN.

I24. Winston to Larkins, September 2I, I946, box 26, Larkins, J.R.-Speech Materials, Correspondence Folder 2 of 3, BWAN. 
These restrictions appeared to have some effect on Larkin's willingness to participate in making a case to county superintendents. In I949, Larkins turned down an appeal from African Americans to help them secure social workers in their counties. In August of that year he received a request from Dr. James Tinsley to accompany a group of "representative" African Americans to their meeting with Halifax County superintendent J. B. Hall regarding the employment of an African American social worker. In refusing the request, Larkins noted a change during "the past several years" in policy. Neither he nor other staff members could "participate in this type of activity." The most Larkins could officially do was to offer aid in the event that the superintendent chose to contact him. ${ }^{125}$ On the same day, however, he wrote what he termed a "personal note" to tell the recipient to "confidentially advise" the group that Larkins supported their effort and suggested a couple of questions for them to raise in their conversation with the county superintendent. ${ }^{\mathrm{I} 26}$ Still, the effect of the policy was that superintendents would no longer have to explain why they did not wish to hire black social workers to state employees like Larkins.

The significance of these social workers changed as well. By the end of the I940s, Larkins's statements suggested that the ideological linkage between interracialism and workers' responsibilities and purpose had weakened. Larkins insisted on the distinction between social work and reform, presenting the former as focused on the individual. His 1947 progress report for Winston noted that in the previous year he had to apprise many people that the unit's goal was simply to help meet "the needs of all individuals" rather than "the securing of civil rights" or ensuring fair application of the law. The unit needed to communicate to the public this "new philosophy and objective." 27 Larkins elsewhere also insisted on its nonpolitical nature and distinguished its mission from the advocacy organizations, such as the National Association for the Advancement of Colored People (NAACP), that attempted to use the law to enforce African Americans' citizenship claims. This was itself not surprising, as many moderate whites in the South were liable to draw false equivalencies between the KKK and the NAACP, perceiving each as a threat to gradualist reform. ${ }^{128}$

However, more striking was his description which imagined social workers in isolation, no longer as figures in interracial discussion and representation. At an American Legion regional post meeting in 1949, Larkins suggested that the aspects of life that public welfare addressed, such as "keeping individuals alive, healthy, well-adjusted, attending school, living in decent homes and securing the basic necessities of life," stood apart from the "full citizenship status"

I25. Larkins to Effie C. Sutton, September 2, I949, box 22, Halifax County folder, BWAN. I26. Larkins to Effie C. Sutton, September 2, I949, box 22, Halifax County folder, BWAN. I27. "Progress Report Unit of Work among Negroes, July I, I946-June 30, I947," 5-6.

I28. Johnson, Reforming fim Crow, 234. 
for which the NAACP strived. ${ }^{129}$ At a state conference of NAACP chapters the next year, he again distinguished the organization's tasks from those of social welfare. He argued that while the civil rights organization focused on "where the person ride on the street car or train, where they attend school, where they eat," the public welfare department addressed "whether they are able to ride if they need, child remain in school," and the maintenance of "a decent standard of living." "130 This description reflected an understanding of social work stripped of its representative and interracial responsibilities. It suggests that the Red Scare and economic growth were not the only reasons for the "retreat from social reform work" and embrace of casework that characterized the social work profession after World War II. ${ }^{\mathrm{I} I \mathrm{I}}$ In North Carolina, that retreat also was shaped by the declining influence of paternalistic interracialism.

\section{CONCLUSION}

While Larkins's responsibilities in the promotion of the employment of African American social workers were seemingly curtailed, the end of the I940s did see a modest increase in their numbers. In August 1945 there were nineteen black workers in twelve counties, out of 350 total workers employed by the state board and individual counties, not including the one hundred county superintendents. ${ }^{132}$ At the end of the year he judged the number of African American social workers to be "very small." 33 In July I946 Larkins noted that there were currently more than twenty black workers "employed in the public

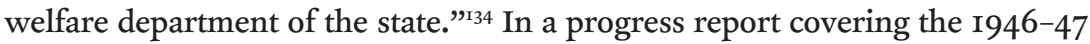
fiscal year, Larkins noted that three counties had hired black workers in that time and that he believed that the following year would see three other counties do the same. ${ }^{135}$ In 1949 county departments employed twenty-four African American social workers. ${ }^{136}$ By December 1952, thirty-two workers were

I29. John Larkins, "Public Welfare in a Democratic Social Order," 5, November I3, I949, box 23, Mecklenburg County folder, BWAN.

I30. John Larkins, "The Role of Public Welfare in Achieving Democracy," June I-2, I950, box 5.5, folder 18, Negroes in Public Welfare in NC, BWAN.

I3I. Bell, Black Power Movement, 74 .

I32. Larkins to Margaret Blee, August 2, I945, box 27, University of N.C., I925-1950 folder, BWAN.

I33. Larkins to P. R. Brown, December I3, I945, box 26.2, Morrison Training School, Paul R. Brown, Supt., I944-I948 folder, BWAN.

I34. Larkins to Gerard Anderson, July 3, I946, box 22, Alamance County I943-I949 folder, BWAN.

I35. "Progress Report Unit of Work among Negroes, July I, I946-June 30, I947," 2-3, box 9, Dr. Ellen Winston-Commission of Public Welfare-I folder, BWAN.

I36. Larkin to Doris P. Raynor, March 26, I949, box 24, Wilson County folder, BWAN. 
employed by sixteen counties, according to Winston, who noted that the employment of African American social workers was "a local matter." 37 Although still considerably less than the approximately forty-eight employed in I933, these numbers were significant in the region. ${ }^{138}$ According to a study by Larkins of African American social workers in eleven southern states published by the North Carolina State Board in I95I, the state employed the second largest number of workers after Louisiana, although statistics were not available for Georgia. ${ }^{139}$

As this article demonstrates, though, tracking the variations in the numbers of workers employed by the state's county welfare departments insufficiently captures the unit's significance. Scrutinizing unit leaders' strategies for increasing the employment of black social workers demonstrates the role of state bureaucracy in maintaining interracial paternalism into the I940s. This mode of interracialism left its mark by shaping the strategies employed by the unit's leaders and the contradictions they faced as they strove to facilitate the employment of African American social workers. The class distinctions celebrated by racial uplift offered a means for asserting black communal representation by those workers within the confines of interracialism. The unit's first leader, Lawrence Oxley, publicly praised whites for not being threatened by educated African Americans. At the same time, he urged black social workers not to contravene the strictures of Jim Crow. During the Great Depression, interracialism did not prove a useful means for protecting or increasing the employment of African American social workers. The unit leader during much of the New Deal relief efforts, William Johnson, impatient with the lack of progress, looked beyond this mode of interaction to buttress his position in his discussions with county public welfare superintendents. He urged the State Board of Charities and Public Welfare to mandate counties with a minimum percentage of African American population hire black social workers. Had it been enacted, such a rule would have significantly reshaped the dynamics of his relations with county superintendents.

Such a rule change did not occur. The distrust of paternalistic interracialism reflected in Johnson's attempt, however, became more evident in the I940s. White authorities and African American activists outside of the unit questioned its ability to manage African Americans' efforts to redress the wrongs of Jim Crow. Within the unit, engagement in paternalistic interracialism was largely

I37. Winston to Dorothy M. Johnson, December 4, I952, box 5.5, folder I8, Negroes in Public Welfare in NC, BWAN.

138. "Minutes of the Meeting of the Negro Advisory Committee," BWAN.

139. John R. Larkins, The Employment of Negroes in Public Welfare in Eleven Southern States, 1936-I949 (Raleigh, NC, I95I), I07. 
excised from the recognized responsibilities of the unit leader and county superintendents in the I940s. The third unit leader, John Larkins, saw his opportunities to engage with county superintendents reduced to times and subjects of the latter's choosing by the mid-I940s. The recently installed state board commissioner Ellen Winston considered the encouragement that he and his predecessors had previously given to public welfare superintendents to hire black workers to be outside the position's purview. White superintendents were free to initiate interracial discussions with Larkins regarding African American social workers, while Larkins lacked that power. The unit leader also could no longer assist local African Americans and guide them in encounters with the white authorities unless those authorities asked for his involvement. In the wake of the disavowal of Jim Crow interracialism, Larkins's own descriptions of the value of black social workers focused on their service to their individual clients rather than any representative and interracial functions.

Larkins's I95I study provided a snapshot of how black social workers in the South themselves were looking to solutions beyond interracialism to address the continued insecurity of their positions. Larkins noted a "wide-spread belief" among these workers that "politics were responsible for some of the major problems" they faced. ${ }^{14}{ }^{\circ}$ A majority of black workers named "limited opportunities and racial restrictions on advancement" as the most important challenge facing them. ${ }^{4 \mathrm{I}}$ One former worker who had left social work linked African Americans' rights as citizens to their fortunes in the profession. This worker argued that local black leaders had been unable to "press their rights to see that Negroes are justly employed in communities where they are needed." The solution to this unsatisfactory state of affairs, this former worker maintained, was to challenge white supremacy through voting. ${ }^{\mathrm{I} 2}$ If politics was the problem, then direct participation in politics could be the solution. This solution transgressed boundaries of paternalism.

I40. Ibid., 98.

I4I. Ibid., 97.

I42. Ibid., 98. 